\title{
Spatial distribution and functional feeding groups of aquatic insects in a stream of Chakrashila Wildlife Sanctuary, Assam, India
}

\author{
B. Barman ${ }^{(1)}$, S. Gupta ${ }^{(1), \star}$ \\ Received March 27, 2015 \\ Revised August 14, 2015 \\ Accepted October 19, 2015
}

Key-words: functional feeding group, aquatic insects, stream ecosystem, Chakrashila Wildlife Sanctuary

\section{ABSTRACT}

Aquatic insects play important role in ecosystem functioning viz. nutrient cycling, primary production, decomposition and material translocation. The functional feeding group (FFG) approach is an attempt to classify organisms, especially insects, according to their role in the processing of organic matter. An investigation during 2011-2013 was carried out on aquatic insects in different stretches of a stream of Chakrashila Wildlife Sanctuary located in western Assam, North East India which is designated as Key Biodiversity Area (KBA) by IUCN. Physico-chemical properties of water of the stream like water temperature, dissolved oxygen, free-carbondioxide, $\mathrm{pH}$, total alkalinity, electrical conductivity, phosphate and nitrate were estimated to correlate the aquatic insects of specific functional feeding groups with water quality. A total of seventeen species was recorded during the study period. Record of nine species in first year and fourteen species in second year under different functional feeding groups (FFG) showed altitudinal variation. Highest percentage of predators was found in upstream. Collectors were recorded in upstream and downstream and shredders were recorded in midstream.

\section{RÉSUMÉ}

Distribution spatiale et groupes fonctionnels alimentaires d'insectes aquatiques dans une rivière du Wildlife Sanctuary Chakrashila, Assam, en Inde

Mots-clés:
groupe
fonctionnel
d'alimentation,
insecte
aquatique,
écosystème
lentique,

Les insectes aquatiques jouent un rôle important dans le fonctionnement de l'écosystème à savoir le cycle des éléments nutritifs, la production primaire, la décomposition et le transfert de matière. L'approche groupe fonctionnel d'alimentation (FFG) est une tentative de classer les organismes, en particulier les insectes, en fonction de leur rôle dans l'utilisation de la matière organique. Une étude en 2011-2013 a été menée sur les insectes aquatiques dans les différents tronçons d'une rivière du Chakrashila Wildlife Sanctuary, situé dans l'ouest de I'Assam, Nord-Est de l'Inde, qui est désigné comme une région clé pour la biodiversité (KBA) par l'UICN. Les propriétés physico-chimiques de l'eau du cours d'eau comme la température de l'eau, l'oxygène dissous, le dioxyde de carbone, le $\mathrm{pH}$, l'alcalinité totale, la conductivité électrique, phosphate et nitrate ont été mesurés pour corréler les insectes aquatiques de groupes fonctionnels 
Chakrashila

Wildlife

Sanctuary d'alimentation spécifiques avec la qualité de l'eau. Un total de dix-sept espèces a été rencontré au cours de la période d'étude. Neuf espèces en première année et quatorze espèces en deuxième année de différents groupes fonctionnels alimentaires (FFG) ont montré une variation altitudinale. Le pourcentage le plus élevé de prédateurs a été trouvé en amont. Les insectes filtreurs ont été trouvés en amont et en aval et les broyeurs dans le secteur médian.

\section{INTRODUCTION}

Aquatic macroinvertebrates are important components in the ecological dynamics of lotic environments. They play significant role in energy fluxes, nutrient cycling and widely used in biomonitoring (Wallace and Webster, 1996; Sandin and Hering, 2004). The term "functional feeding group" was first used by Cummins (1974), who stated that it is necessary to identify functional groups of organisms, at least partially independent of taxonomic determinations, in order to address important process-oriented ecosystem questions. Functional-group analyses were developed initially for small streams (Cummins, 1973, 1974) and as key components of the river continuum concept (RCC) (Vannote et al., 1980). The functional feeding groups reflect the four most important food resources found in streams: periphyton, coarse particulate organic matter, fine particulate organic matter, and animal prey. Shredders feed on coarse particulate organic matter, collectors feed on fine particulate organic matter either from the water column or the streambed, scrapers ingest periphyton, and predators consume prey (Cummins and Klug, 1979; Merritt and Cummins, 1996). Again there are some groups of insects which function as both predator and scavenger (pre-Scavenger), i.e. feeds on live or dead zooplankton and also consume prey (Spence and Anderson, 1994). According to Allan and Castillo (2007) distribution of functional feeding groups are determined by mechanisms of food acquisition and changes in food availability which indeed is influenced by stream size, shading and substrate. Considering the importance of the functional feeding group approach in biomonitoring and conservation, the assessment of the functional organization of macroinvertebrate community turns out to be essential (Príncipe et al., 2010). Besides, it provides basic knowledge for the identification of policies and proposal for conservation and maintenance use of natural resources of a given area (Oliveira and Nessimian, 2010).

Chakrashila Wildlife Sanctuary, Assam through which Bhalukjhora stream flows is the second home of Golden Langur (Trachypithecus geei) located in the biodiversity hotspot Himalaya. Since aquatic insects are used worldwide for biomonitoring of water quality and there is lack of information about the functional feeding groups in the streams of North Eastern India, this study aims to describe the composition and spatial distribution of aquatic insect communities in different stretches of Bhalukjhora stream of the protected area and analyze the functional feeding trophic structure of the community.

\section{MATERIALS AND METHODS}

\section{> STUDY AREA}

Chakrashila Wildlife Sanctuary (CWS) (26 $16^{\prime}$ to $26^{\circ} 26^{\prime} \mathrm{N}$ and $90^{\circ} 15^{\prime}$ to $\left.90^{\circ} 20^{\prime} \mathrm{E}\right)$ is located in the Dhubri and Kokrajhar district of Assam, North East India. The stream Bhalukjhora $\left(26^{\circ} 19^{\prime} \mathrm{N}\right.$ and $\left.90^{\circ} 17^{\prime} \mathrm{E}\right)$ is the first order stream flowing about $1 \mathrm{~km}$ within the Sanctuary out of its total length of $5.13 \mathrm{~km}$ (Table I, Figure 1). 


\section{Table I}

GPS locations of different stretches of the Bhalukjhora stream of Chakrashila Wildlife Sanctuary.

\begin{tabular}{|l|c|c|c|}
\hline Stretches & Latitude (N) & Longitude (E) & Altitude (m) \\
\hline Upstream & $26^{\circ} 19^{\prime} 35.1^{\prime}$ & $90^{\circ} 17^{\prime} 20.5^{\prime}$ & 74 \\
\hline Midstream & $26^{\circ} 19^{\prime} 27.2^{\prime}$ & $90^{\circ} 17^{\prime} 18.5^{\prime}$ & 68 \\
\hline Downstream & $26^{\circ} 19^{\prime} 22.5^{\prime}$ & $90^{\circ} 17^{\prime} 17.3^{\prime}$ & 58.5 \\
\hline
\end{tabular}

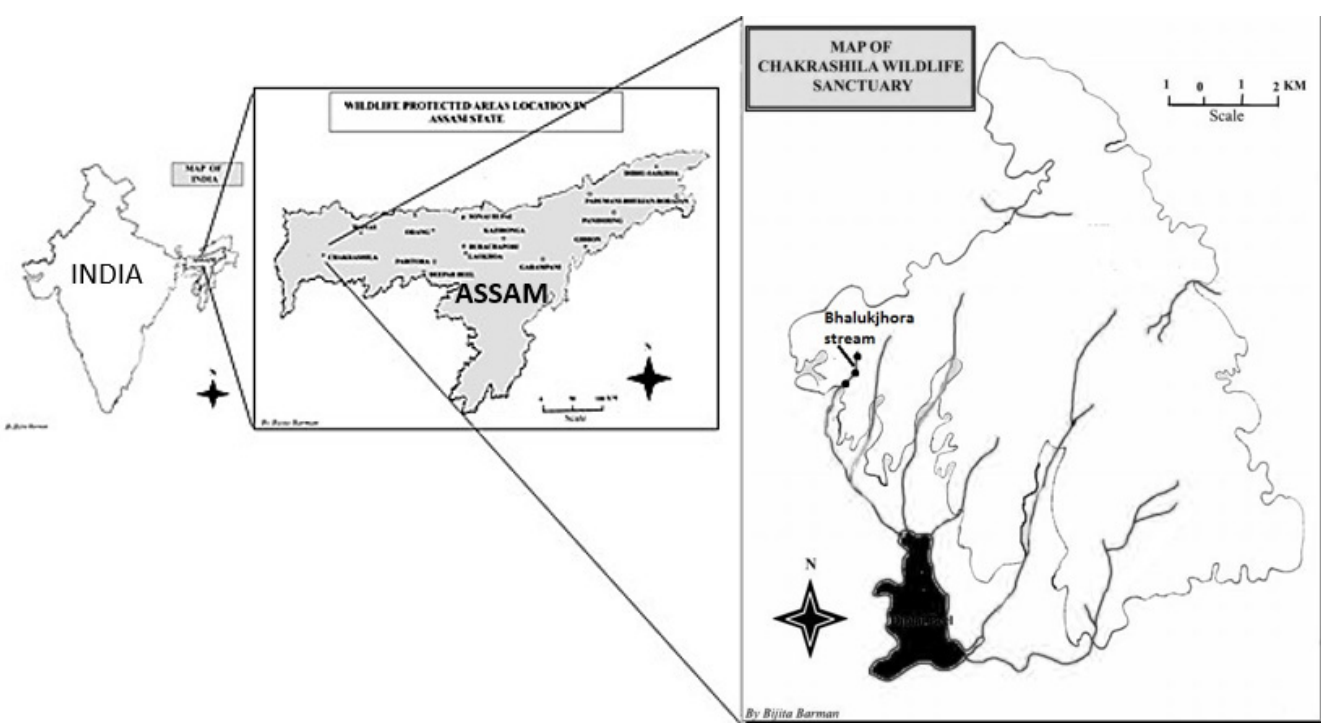

\section{Figure 1}

Map showing the position of CWS in Himalayan Biodiversity Hotspot and the Bhalukjhora stream in Chakrashila Wildlife Sanctuary.

\section{> SAMPLING}

Samples were collected seasonally during 2011-2013 from three different stretches of the stream: upstream (US), midstream (MS) and downstream (DS) (Table I) in three replicates. Insects were collected by "all out search" method, a nylon pond net method (Subramanian and Sivaramakrishnan, 2007) and 1 min kick method (Brittain, 1974) using hand net (mesh size $40 \mu \mathrm{m}$ ), a circular net (mesh size $60 \mu \mathrm{m}$ ) and kick-net (mesh opening: $180 \mu \mathrm{m}$; net area $1 \mathrm{~m}^{2}$ ), respectively. Samples were fixed and preserved in $70 \%$ alcohol, sorted and identified under stereoscopic microscopes (Motic, Model- SMZ-168). Identification of organisms was performed to the lowest taxonomic level possible with the aid of taxonomic keys (Thirumalai, 1999; Webb and Suter, 2001; Thirumalai, 2002; Jessup et al., 2003; Bouchard, 2004; Nieser, 2004; Miller, 2005; Braasch, 2006; Epler, 2006; Bouchard, 2009; Webb and Suter, 2011). Functional feeding groups of aquatic insects were identified based on Merritt and Cummins (1996), Merritt et al. (2005) and Baptista et al. (2006).

Environmental variables such as electric conductivity, EC $\left(\mu \mathrm{S} \cdot \mathrm{cm}^{-1}\right) ; \mathrm{pH}$; flow rate, $\mathrm{FR}$ $\left(\mathrm{m}^{3} \cdot \mathrm{S}^{-1}\right)$; water temperature, WT $\left({ }^{\circ} \mathrm{C}\right)$; dissolved oxygen, DO $\left(\mathrm{mg} \cdot \mathrm{L}^{-1}\right)$; free-carbondioxide, $\mathrm{F}-\mathrm{CO}_{2}\left(\mathrm{mg} \cdot \mathrm{L}^{-1}\right)$; total alkalinity, TA $\left(\mathrm{mg} \cdot \mathrm{L}^{-1}\right)$; phosphate $\left(\mathrm{mg} \cdot \mathrm{L}^{-1}\right)$ and nitrate $\left(\mathrm{mg} \cdot \mathrm{L}^{-1}\right)$ were measured by standard methods (Trimmer, 1994; APHA, 2005).

\section{> DATA ANALYSIS}

Species diversity was calculated using the Shannon-Wiener index $\left(H^{\prime}\right)$, Evenness index $\left(J^{\prime}\right)$, Berger-parker index of Dominance (d) and Margaleff's index of water quality (M) using the package Biodiversity Professional Version 2 for Windows 1997. SIGNAL (Stream Invertebrate Grade Number- Average Level), a family-level water pollution index based on the known tolerances of aquatic macro-invertebrate families to various pollutants was worked out by the 
Table II

Environmental variables of water of different stretches of Bhalukjhora stream.

\begin{tabular}{|l|c|c|c|c|c|c|}
\cline { 2 - 7 } \multicolumn{1}{c|}{} & \multicolumn{3}{c|}{$1^{\text {st }}$ year (Stretches) } & \multicolumn{3}{c|}{$2^{\text {nd }}$ year (Stretches) } \\
\hline $\begin{array}{l}\text { Environmental } \\
\text { Variables }\end{array}$ & Upstream & Midstream & Downstream & Upstream & Midstream & Downstream \\
\hline $\begin{array}{l}\text { Rainfall (cm) } \\
\text { Water } \\
\begin{array}{l}\text { Temperature } \\
\left({ }^{\circ} \mathbf{C}\right)\end{array}\end{array}$ & $28.09 \pm 11.52$ & $28.09 \pm 11.52$ & $28.09 \pm 11.52$ & $39.98 \pm 14.2$ & $39.98 \pm 14.2$ & $39.98 \pm 14.2$ \\
\hline $\begin{array}{l}\text { Flow-rate } \\
\left(\mathbf{m}^{3} \cdot \mathbf{S}^{-1}\right)\end{array}$ & $520.18 \pm 8.49$ & $531.6 \pm 8.30$ & $410.52 \pm 6.70$ & $99.08 \pm 1.96$ & $282.55 \pm 13.1$ & $254.93 \pm 6.46$ \\
\hline $\begin{array}{l}\text { Dissolved } \\
\text { Oxygen } \\
\left(\mathbf{m g} \cdot \mathbf{L}^{-1}\right)\end{array}$ & $7.87 \pm 2.08$ & $7.80 \pm 1.4$ & $7.11 \pm 0.99$ & $12.40 \pm 1.33$ & $11.90 \pm 3.28$ & $10.70 \pm 1.86$ \\
\hline $\begin{array}{l}\text { Free-CO } \\
\left(\mathbf{m g} \cdot \mathbf{L}^{-1}\right)\end{array}$ & $4.96 \pm 2.9$ & $5.42 \pm 3.3$ & $5.65 \pm 3.4$ & $7.58 \pm 0.17$ & $6.98 \pm 0.47$ & $5.36 \pm 0.28$ \\
\hline $\begin{array}{l}\text { Total } \\
\text { Alkalinity } \\
\left(\mathbf{m g} \cdot \mathbf{L}^{-1}\right)\end{array}$ & $37.07 \pm 2$ & $30.62 \pm 3.2$ & $48.06 \pm 1.8$ & $28.02 \pm 2.36$ & $31.68 \pm 0.29$ & $31.63 \pm 0.39$ \\
\hline pH & $6.44 \pm 0.29$ & $6.41 \pm 0.24$ & $6.39 \pm 0.12$ & $6.56 \pm 0.13$ & $6.47 \pm 0.02$ & $6.46 \pm 0.14$ \\
\hline $\begin{array}{l}\text { Electrical } \\
\text { Conductivity } \\
\left(\boldsymbol{\mu S} \cdot \mathbf{c m}^{-1}\right)\end{array}$ & $31.93 \pm 5.4$ & $32.62 \pm 4.3$ & $37.95 \pm 7.2$ & $44.36 \pm 6.68$ & $37.68 \pm 0.68$ & $49.90 \pm 7.96$ \\
\hline $\begin{array}{l}\text { Phosphate } \\
\left(\mathbf{m g} \cdot \mathbf{L}^{-1}\right)\end{array}$ & $0.08 \pm 0.06$ & $0.18 \pm 0.14$ & $0.10 \pm 1$ & $0.37 \pm 0.03$ & $0.27 \pm 0.2$ & $0.20 \pm 0.2$ \\
\hline $\begin{array}{l}\text { Nitrate } \\
\left(\mathbf{m g} \cdot \mathbf{L}^{-1}\right)\end{array}$ & $0.10 \pm 0.07$ & $0.10 \pm 0.027$ & $0.61 \pm 0.94$ & $0.05 \pm 0.02$ & $0.12 \pm 0.02$ & $0.61 \pm 0.34$ \\
\hline
\end{tabular}

standard method (Chessman, 1995). BMWP (Biological Monitoring Working Party) and ASPT (Average Score Per Taxon) scores were computed (Armitage et al., 1983; Hawkes, 1998). Statistical analyses were done by SPSS 16 for Windows 7. Canonical Correspondence analysis (CCA) was done using CANOCO for windows 4.5 (Ter Braak, 1986, 1987, 1988).

\section{RESULTS}

\section{> ENVIRONMENTAL VARIABLES}

The annual variations in environmental factors along the different stretches of the stream for two years are shown in Table II. The flow rate of the stream was found highest in midstream in both the years, higher in first year $\left(531.6 \mathrm{~m}^{3} \cdot \mathrm{S}^{-1}\right)$ than that of second year $\left(282.55 \mathrm{~m}^{3} \cdot \mathrm{S}^{-1}\right)$. Rainfall was $39.98 \mathrm{~cm}$ in the second year while $28.09 \mathrm{~cm}$ in the first year. The DO showed very narrow range of fluctuation, $\left(7.11-7.87 \mathrm{mg} \cdot \mathrm{L}^{-1}\right)$ in first year and it was comparatively higher in second year (10.7-12.4 mg. $\left.\mathrm{L}^{-1}\right)$. $\mathrm{pH}$ was found slightly acidic (6.39-6.44 and 6.46-6.56 in first and second year, respectively). In the first year phosphate concentration was recorded highest $\left(0.18 \mathrm{mg} \cdot \mathrm{L}^{-1}\right)$ in midstream and in the second year it was found highest $\left(0.37 \mathrm{mg} \cdot \mathrm{L}^{-1}\right)$ in the upstream. Concentration of nitrate ranged from 0.1 to $0.61 \mathrm{mg} \cdot \mathrm{L}^{-1}$ and 0.05 to $0.61 \mathrm{mg} \cdot \mathrm{L}^{-1}$ in the first and second year, respectively.

\section{> SPATIAL DISTRIBUTION AND AQUATIC INSECT COMPOSITION}

A total of 17 species belonging to 17 genera, 11 families and 5 orders were recorded in the two years of study. In the first year 9 aquatic insect species belonging to 2 orders, Ephemeroptera 


\section{Table III}

Altitudinal variations in dominance status of different species of aquatic insects in Bhalukjhora stream based on Engelmann's Scale (1978) with Functional Feeding Group (FFG) category.

\begin{tabular}{|c|c|c|c|c|c|c|c|c|c|}
\hline \multirow[t]{2}{*}{ Order } & \multirow[t]{2}{*}{ Family } & \multirow[t]{2}{*}{ Taxa } & \multirow[t]{2}{*}{ FFG } & \multicolumn{3}{|c|}{$\begin{array}{l}1^{\text {st }} \text { year } \\
\text { (Stretches) }\end{array}$} & \multicolumn{3}{|c|}{$\begin{array}{l}2^{\text {nd }} \text { year } \\
\text { (Stretches) }\end{array}$} \\
\hline & & & & Up & \begin{tabular}{|l|} 
Mid \\
\end{tabular} & Down & Up & Mid & Down \\
\hline \multirow[t]{11}{*}{ Hemiptera } & Gerridae & Ptilomera assamensis & Pre & $\mathrm{D}$ & $\mathrm{D}$ & $\mathrm{D}$ & SD & $\mathrm{D}$ & $\mathrm{D}$ \\
\hline & & Metrocoris sp. & Pre & ED & ED & D & ED & D & D \\
\hline & & Ovatametra sp. & Pre & - & $\mathrm{R}$ & - & - & - & - \\
\hline & & Rheumatogonous sp. & Pre & SR & - & - & - & - & SR \\
\hline & & Rhagodotarsus sp. & Pre & - & - & - & - & - & SR \\
\hline & Veliidae & $\begin{array}{l}\text { Rhagovelia } \\
\text { sumatrensis }\end{array}$ & Pre-Sc & $\mathrm{D}$ & ED & ED & ED & ED & ED \\
\hline & & Microvelia plumbea & Pre & - & - & - & SD & SR & - \\
\hline & Mesoveliidae & Mesovelia vittigera & Pre-Sc & - & - & $\mathrm{R}$ & - & - & - \\
\hline & Nepidae & Ranatra varipes & Pre & SR & - & - & & & - \\
\hline & & $\begin{array}{c}\text { Cercotmetus } \\
\text { brevipes brevipes }\end{array}$ & Pre & & & & - & - & SR \\
\hline & Aphelocheiridae & Aphelocheirus sp. & Pre & SR & - & - & - & - & - \\
\hline \multirow[t]{4}{*}{ Coleoptera } & Curculionidae & Bagous sp. & Shr & - & - & - & - & SR & - \\
\hline & Gyrinidae & Orectogyrus sp. & Pre & - & - & - & - & SR & $\mathrm{R}$ \\
\hline & Hydrophilidae & Helochares sp. & Shr & - & - & - & $\mathrm{SR}$ & - & - \\
\hline & & Enochrus sp. & Co & - & - & - & SR & - & - \\
\hline Ephemeroptera & Baetidae & Offadens sp. & Co & $\mathrm{SR}$ & - & - & - & - & SR \\
\hline Diptera & Dixidae & Nothodixa sp. & Co & - & - & - & - & - & SR \\
\hline Trichoptera & $\begin{array}{l}\text { Polycentropo- } \\
\text { didae }\end{array}$ & Polycentropus sp. & Pre & - & - & - & - & $\mathrm{SR}$ & - \\
\hline
\end{tabular}

(Relative Abundance $<1 \%=$ Subrecedent (SR); 1.1-3.1\% = Recedent (R); 3.2-10\% = Subdominant (SD); $10.1-31.6 \%=$ Dominant $(\mathrm{D}),>31.7 \%=$ Eudominant $(E D))$. (Pre = predator, Pre-Sc= predatorScavenger, Shr $=$ Shredders Co $=$ Collector $)$.

(1 family) and Hemiptera (5 families) were recorded. In the second year of study, 14 aquatic insect species belonging to 5 orders; Trichoptera, Ephemeroptera, Diptera, each represented by one family, and Coleoptera, Hemiptera, each represented by three families were recorded.

During the study period distribution of taxa across stretches showed occurrence of Ranatra varipes and Aphelocheirus sp. only in US; Ovatametra sp., Bagous sp., and Polycentropus sp. only in MS, and Cercotmetus brevipes brevipes, Rhagodotarsus sp., Nothodixa sp. and Mesovelia vittigera only in DS. Ptilomera assamensis, Metrocoris sp., Rhagovelia sumatrensis were found in all the stretches in both the years (Table III).

Metrocoris sp., Rhagovelia sumatrensis, Ptilomera assamensis were the dominant species in the stream in both the years. According to Engelmann's scale of Dominance (1978) Metrocoris sp. was found eudominant in upstream; Rhagovelia sumatrensis was found eudominant in both mid and downstream in both the years (Table III). In the first year in MS along with Rhagovelia sumatrensis; Metrocoris sp. was also found eudominant (Table III).

In the first year among all the stretches although highest species richness (7 taxa out of 9 taxa) was recorded in US, it showed lowest Shannon $H^{\prime}\left(H^{\prime}=0.459\right)$ and Evenness $\left(J^{\prime}=0.543\right)$ and highest Berger parker index of dominance $(d=0.58)$. In contrast in MS, the species richness was found lowest (4 taxa) accompanied by highest Shannon $H^{\prime}\left(H^{\prime}=0.519\right)$, highest Evenness $\left(J^{\prime}=0.742\right)$ and lowest Berger parker index of dominance $(d=0.36)$. In the second year highest Evenness was found in US $\left(J^{\prime}=0.664\right)$ while highest Shannon $H^{\prime}(0.552)$ with lowest Berger parker index of dominance $(d=0.402)$ was recorded in DS (Table IV). In the second year MS had lowest Shannon $H^{\prime}(0.467)$ and Evenness $\left(J^{\prime}=0.55\right)$ values with highest Berger parker index of dominance $(d=0.553)$. The highest Biological Monitoring Working 


\section{Table IV}

Altitudinal variations in the diversity and biotic indices based on aquatic insects of Bhalukjhora stream.

\begin{tabular}{|l|c|c|c|c|c|c|}
\hline \multirow{2}{*}{ Index } & \multicolumn{3}{|c|}{$1^{\text {st }}$ year (Stretches) } & \multicolumn{3}{c|}{$2^{\text {nd }}$ year (Stretches) } \\
\cline { 2 - 7 } & Upstream & Midstream & Downstream & Upstream & Midstream & Downstream \\
\hline Shannon H' & 0.459 & 0.519 & 0.479 & 0.517 & 0.467 & 0.552 \\
Log Base 10. & & & & & & \\
Shannon J' & 0.543 & 0.742 & 0.685 & 0.664 & 0.552 & 0.578 \\
Berger-Parker & 0.58 & 0.356 & 0.503 & 0.475 & 0.553 & 0.402 \\
Dominance (d) & & & & & & 5.629 \\
Margaleff M & 4.294 & 4.517 & 4.569 & 5.639 & 5.264 & \\
Base 10. & & & & & & \\
BMWP Score & 34 & 19 & 24 & 15 & 32 & 29 \\
ASPT Score & 6.8 & 6.3 & 6 & 7.5 & 6.4 & 5.8 \\
SIGNAL Score & 3.08 & 3.36 & 3.17 & 4.39 & 4.28 & 4.25 \\
\hline
\end{tabular}

BMWP score: 0-16 = Poor water quality; 17-50 = Moderate water quality; 51-100 = Good water quality; 101-150 = High water quality; $151+=$ Very high water quality (Chesters, 1980)

ASPT score: $>6=$ Clean water (Chesters, 1980)

SIGNAL Score: Greater than $6=$ Healthy habitat, Between 5 and $6=$ Mild pollution, Between 4 and $5=$ Moderate Pollution, Less than 4 = Severe pollution (Gooderhum and Tsyrlin, 2002).

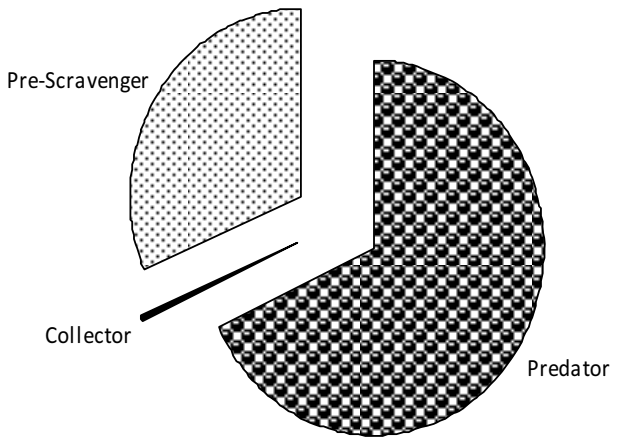

(a)

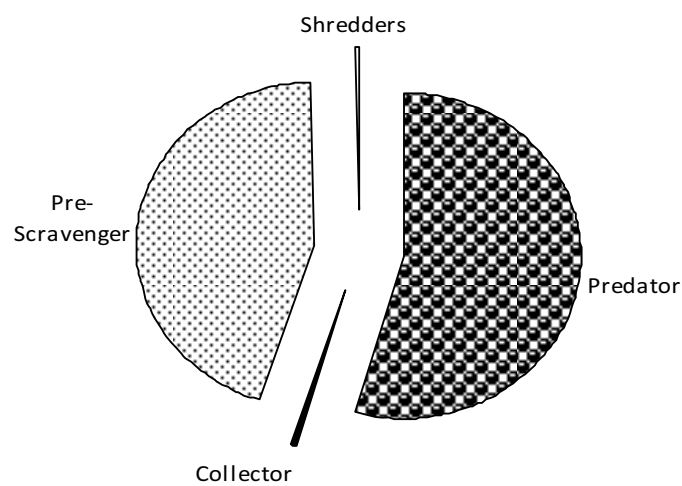

(b)

Figure 2

(a, b) Percentage composition of FFGs in first (a) and second (b) year in Bhalukjhora stream.

Party (BMWP) score among the different stretches of the stream was found in US (34) in the first year and MS (32) in the second year. However the Average Score per Taxon (ASPT) scores were found more than 6 in all the stretches in both the years except in DS (5.8) in second year (Table IV). The ranges of SIGNAL score were 3.05-3.36 and 4.25-4.39 in first and second year, respectively.

\section{> FUNCTIONAL FEEDING GROUPS}

In all the stretches predator was the main functional feeding group (68\%), followed by prescavenger $(31.28 \%)$, and collector $(0.67 \%)$ in the first year whereas in the second year, percentage composition of predator (55\%) although highest was very close to pre-scavenger $(45 \%)$ followed by collector $(0.4 \%)$ and shredders $(0.14 \%)$ (Figures $2 a$ and $2 b)$. The percentage compositions of predator, collector and pre-scavenger in first year in US were $81.28 \%$, $0.46 \%$, and $18.26 \%$, respectively; in MS were $63.28 \%, 1.13 \%$, and $35.59 \%$, respectively and in DS were $58.05 \%, 0.49 \%$ and $41.46 \%$ respectively. Again in the second year the percentage compositions of predator, collector, pre-scavenger and shredders in US were $68 \%, 0.52 \%$, 


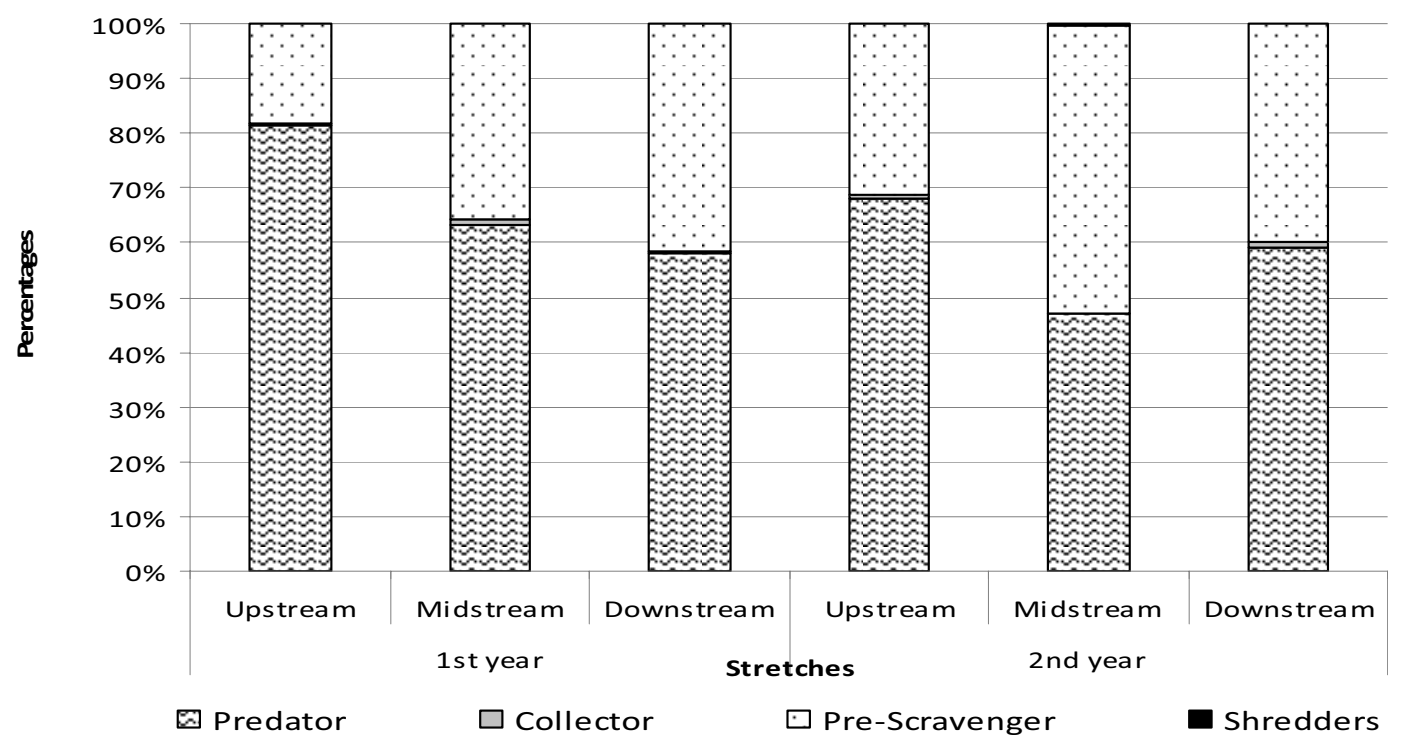

Figure 3

Relative abundance of different functional feeding groups in three different stretches of Bhalukjhora stream during first and second year.

Table $V$

Summary statistics of CCA between aquatic insect species and environmental variables for 1st and 2nd year and CCA between functional feeding groups and environmental variables (total study period) for first two axes in Bhalukjhora stream.

\begin{tabular}{|c|c|c|c|c|c|c|c|c|c|c|c|}
\hline & \multicolumn{4}{|c|}{ 1st year } & \multicolumn{4}{|c|}{ 2nd year } & \multicolumn{3}{|c|}{ FFG } \\
\hline & Axis 1 & Axis 2 & $\sqrt{\text { Axis } 8}$ & $\mid$ Total & $\sqrt{\text { Axis } 1}$ & Axis 2 & $\sqrt{\text { Axis } 3}$ & Total & $\sqrt{\text { Axis } 1}$ & Axis 2 & Total \\
\hline Eigen values & 0.003 & 0.12 & 0.081 & 0.205 & 0.17 & 0.065 & 0.00 & 0.235 & 0.046 & 0.016 & 0.062 \\
\hline Cumulative Perc & 1.6 & 60.4 & 100.0 & & 72.4 & 100.0 & & & 74.2 & 100 & \\
\hline $\begin{array}{l}\text { of species-environment } \\
\text { relation }\end{array}$ & 100.0 & 0.0 & 0.0 & & 72.4 & 100.0 & & & 74.2 & 100 & \\
\hline $\begin{array}{l}\text { Species-environment } \\
\text { correlations }\end{array}$ & 0.165 & 0.000 & 0.000 & & 1.00 & 1.00 & 0.00 & & 1.00 & 1.00 & \\
\hline
\end{tabular}

$31.4 \%$ and $0 \%$ respectively; in MS were $47 \%, 0 \%, 53 \%$ and $0.36 \%$ respectively and in DS were $59 \%, 0.98 \%, 40 \%$ and $0 \%$ respectively (Figure 3).

The association of aquatic insect species with environmental variables in different stretches as revealed by CCA is shown in Table $\mathrm{V}$. The eigenvalues $0.003,0.12$ and 0.081 for the axis 1 , axis 2 and axis 3 explained $1.6 \%, 60.4 \%$ and $100 \%$ of variance respectively and the speciesenvironment correlations of CCA axis 1 were found to be 0.165 in first year. In second year, the eigenvalues 0.17 and 0.065 for the axis 1 and axis 2 explained $72.4 \%$ and $100 \%$ of variance respectively and the species-environment correlations of CCA axis 1 were found to be 1 . In the present study the total eigenvalues were 0.205 in first year and 0.235 in second year, respectively. The CCA ordination diagram showed association of different insect species with the environmental variables in the three different stretches (Figures $4 a$ and $4 b$ ). The CCA ordination diagram clearly separated the stretches on the basis of the aquatic insect community composition. The direction and length of each arrow indicated the direction and rate of maximum change in each variable. All the environmental variables were found to be more or less associated with different insect species along the altitudinal gradients in both the years. In the first year $\mathrm{pH}$ and $\mathrm{F}-\mathrm{CO}_{2}$ was found to be strongly associated with axis 1 while RF and TA with axis 2 . In the second year axis 1 was strongly associated with phosphate and WT and axis 2 only with EC. In US in the first year, the three species Rheumatogonous sp., Aphelocheirus $\mathrm{sp}$. and Ranatra varipes of order Hemiptera were found inversely associated with most of the 


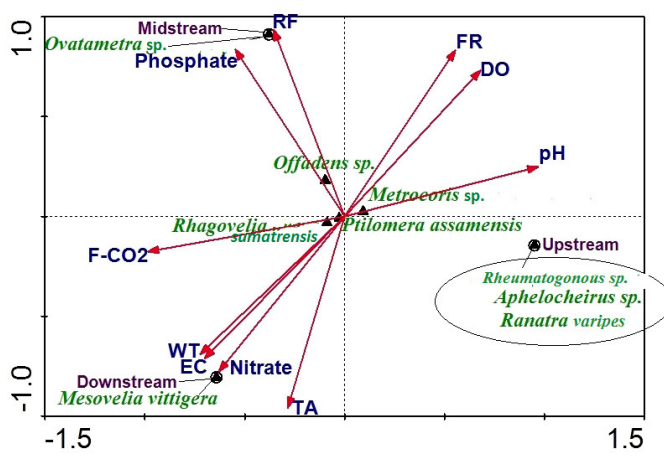

(a)

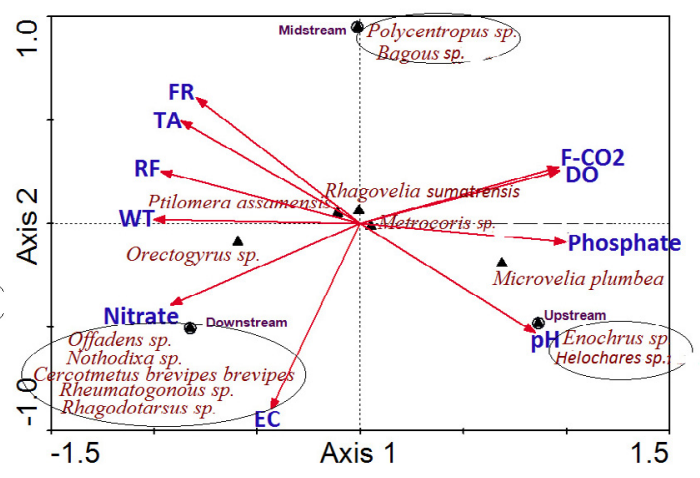

(b)

\section{Figure 4}

(a, b) Triplot of a Canonical Correspondence Analysis (CCA) showing associations between different species of aquatic insects (triangles $\mathbf{\Delta}$ ) and environmental variables from the three stretches (Circle $O$ ) in first (a) and second (b) year of study. Relationships between variables or similarity of samples are indicated by close clusters of points.

measured variables while in the second year recorded species Halochares sp., Enochrus sp., Microvelia plumbea belonging to Coleoptera and Hemiptera showed positive correlation with $\mathrm{pH}$ and phosphate (Figures $4 \mathrm{a}$ and $4 \mathrm{~b}$ ). Positive associations of Offadens sp. and Ovatametra $\mathrm{sp}$. with phosphate and RF in mid-stream in the first year and positive association of Offadens sp. with nitrate in the second year in DS were found.

\section{> FUNCTIONAL FEEDING GROUP AND ENVIRONMENTAL VARIABLES}

The association of functional feeding groups with environmental variables in different stretches for two years of study as revealed by CCA is shown in Table $\mathrm{V}$. The eigenvalues 0.046 and 0.016 for the axis 1 and axis 2 explained $74.2 \%$ and $100 \%$ of variance respectively and the species-environment correlations of CCA axis 1 were found to be 1 . In the present study the correspondence was measured among the functional feeding group, stretches and environmental variables, thus the total eigenvalue 0.062 indicated a low degree of correspondences between FFG and stretches. The CCA ordination diagram showed associations of different functional feeding groups with the environmental variables in the three different stretches (Figure 5). In the CCA ordination diagram predator group of both the years were found positively associated with $\mathrm{pH}$. Pre-scavenger group of first year was found positively associated with WT and nitrate while Pre-scavenger group of second year was negatively associated with FR. The collector in US, DS of first year and shredders in the MS of second year were positively associated with phosphate.

\section{DISCUSSION}

The range of DO of the Bhalukjhora stream water was found within the normal range of DO (5 to13 $\mathrm{mg} \cdot \mathrm{L}^{-1}$ ) in the stream water (EPA, 2010) and considered very good for most stream biotas (Sharon, 1997). The pH range from 6.5 to 8.5 is permissible as per BIS (2004) and WHO (2011). Although pH usually has no direct impact on consumers it is one of the most important operational water quality parameters. Popoola and Otalekor (2011) recorded pH range of 6.0-7.0 in Awba reservoir, Nigeria. High phosphate concentration in the stream water ranging from $0.18 \mathrm{mg} \cdot \mathrm{L}^{-1}$ to $0.37 \mathrm{mg} \cdot \mathrm{L}^{-1}$ is remarkable. High concentration of phosphate (0.652 $\mathrm{mg} \cdot \mathrm{L}^{-1}$ ) was also recorded in the Yamuna River, Doon valley, Uttarakhand, India (Ishaq and Khan, 2013). The high concentration phosphate in upstream during second year is may be due to forest management practices. Forest operations such as drainage, harvesting and 


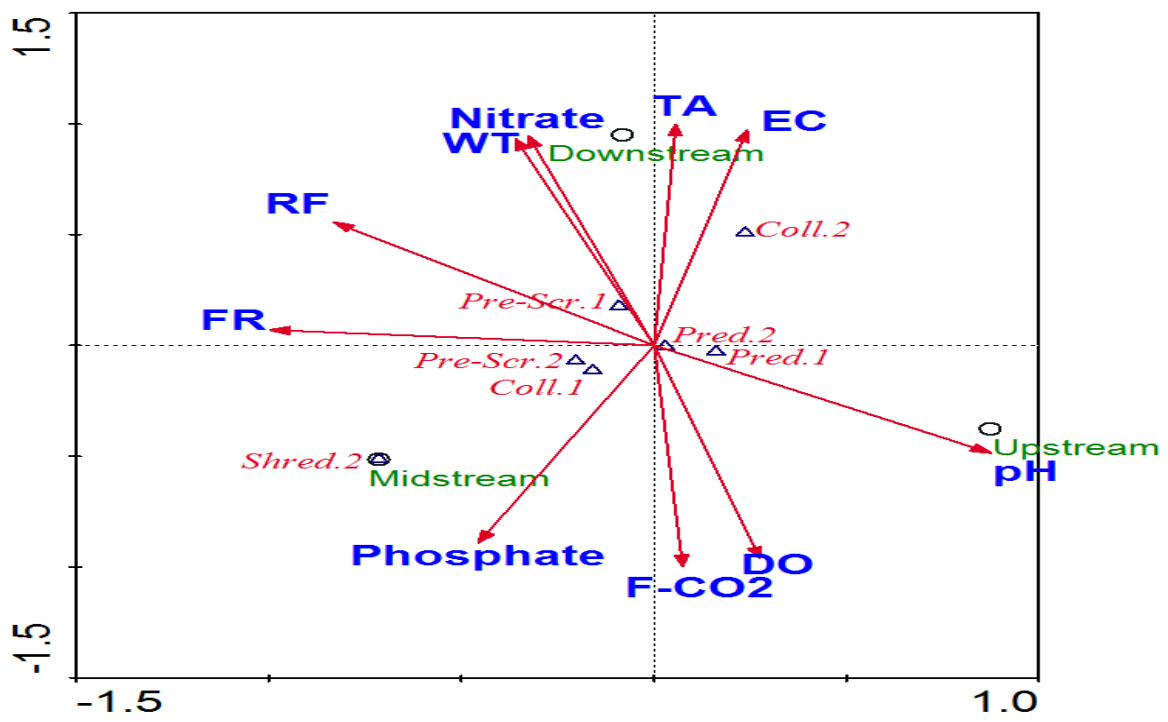

\section{Figure 5}

Triplot of a Canonical Correspondence Analysis (CCA) showing associations between different functional feeding groups (triangles $\mathbf{\Lambda}$ ) and environmental variables (arrow) from the three stretches (Circle $O$ ) in two years of study. (Pred. $=$ Predator, Pre-Scr. $=$ Pre-Scavenger, Coll. $=$ Collector, Shred. $=$ Shredder, 1 indicates for first year and 2 indicates for second year).

reforestation result in increased $P$ release (Ensign and Mallin, 2001; Cummins and Farrell, 2003), and may results increase of $P$ concentration of receiving water bodies (Nisbet, 2001; Cummins and Farrell, 2003). Other important sources of phosphorus to freshwater are atmospheric precipitation, geochemical condition and ground water. In the present study the highest nitrate concentration was found $\left(0.61 \mathrm{mg} \cdot \mathrm{L}^{-1}\right)$ at downstream during both the years. In natural aerobic water, most nitrogen occurs as nitrates in varying amount depending upon the nature of water shed, seasons, degree of pollution and the abundance of plankton (Maitland, 1978). In the Point Calimere Wildlife Sanctuary, South-east coasts of India nitrate values varied from 0.11 to $0.90 \mathrm{mg} \cdot \mathrm{L}^{-1}$ (Manikannan et al., 2011).

In the present study the most of the species were found to belong to the family Gerridae, order Hemiptera. According to Lekprayoon (2007) in terms of abundance and species diversity from lotic habitats, Gerridae is the commonest. The highest relative abundance of species belonging to Gerridae and Veliidae might be because they belong to the infraorder Geeromorpha, skate on the surface of the water bodies with relatively low interaction with water (Bouchard, 2004). In the present study during both the years the genus Metrocoris was found abundant and eudominant in up and midstream and was not found eudominant in pools of downstream. This conformed to the findings of Subramanian and Sivaramakrishnan (2005) in the streams of Western Ghats.

In the present study the highest Shannon $H^{\prime}$ was found in midstream $(0.519,1$ st year) and in downstream $(0.552,2$ nd year). In the headwater streams of northeastern Ohio highest species richness and Shannon $H^{\prime}$ was also recorded in downstream (Holmes et al., 2011). In all the stretches in both the years Shannon $H^{\prime}$ was found less than 1 indicating disturbed condition of the stream (Wilhm and Dorris, 1968). Intrinsic habitat parameters (cascades, pools, riffles and microhabitat richness) and extrinsic factors (environmental variables, altitude, per cent canopy cover) play a role in determining the diversity of aquatic insects (Subramanian and Sivaramakrishnan, 2005; Boulton et al., 2008; Heino, 2009). Margaleff index was more than 3 in both the years indicating good water quality (Lenat et al., 1980).

The highest Biological Monitoring Working Party (BMWP) score among the different stretches of streams indicated moderate water quality in both the years (Chesters, 1980). The ASPT represents the average tolerance score of all taxa within the community, and is calculated by dividing the BMWP by the number of families. A high ASPT usually characterizes clean sites with relatively large numbers of high scoring taxa (Mandaville, 2002). In the present study 
the scores being more than 6 in all the stretches except in DS during second year indicated clean condition of the stream. The ranges of SIGNAL score during both the years being 4 to 5 indicated moderate water quality of the system (Gooderham and Tsyrlin, 2002).

Among the different functional feeding groups predator percentage was higher than that of other groups in all the stretches except one occasion. Similarly in the River Moirang of Manipur, N.E. India the relative abundance of order Hemiptera (mostly predators and prescavengers) was found highest throughout the year (Takhelmayum et al., 2013). The predator group of the stream was mainly represented by aquatic and semi aquatic Hemipterans, swim with oar-like hind legs or can walk on water by surface tension, usually breathe by the means of an air store, and have prominent eyes and are found in all the possible aquatic environments including alpine lakes, hot springs, saline ponds, temporary rock pools, perennial and intermittent streams, and temporary and permanent ponds (Menke, 1979; Polhemus, 1984). The relatively larger size of some aquatic Heteroptera (Belostomatidae, Nepidae, Notonectidae) often makes these insects top predators in systems lacking vertebrates (Waters, 1977; Runck and Blinn, 1990). In the present study the predator Hemipteran families included Gerridae, Veliidae, Aphelocheiridae and Nepidae. Thus predominance of predators along the whole altitudinal gradients of the stream was may be due to availability of food and less competition because these taxa are more abundant in small intermittent streams where fishes are absent (Rieradevall et al., 1999). Although there was no systematic study on the abundance of fishes in the streams of Chakrashila, according to the inhabitants insectivorous fishes are less in the stream. Some studies conducted in many streams of North-east India revealed mostly occurrence of herbivorous fishes like Schizothorax molesworthi, S. progastus, Ctenopharyngodon idella and a few carnivorous fishes like Salmotruta fario, Mystus bleekeri, Ompok pabda (Gurung et al., 2013). The lowest percentage of the functional feeding group shredders conformed to the findings of several studies in tropics (Dudgeon, 1999; Freitag, 2004). In temperate streams leaf litter breakdown is facilitated by shredders where as in tropical streams the role may be played by microbial activity, enhanced by high water temperatures. Thus shredders are often rare in tropical stream (Irons et al., 1994; Dudgeon and Wu, 1999).

Canonical Correspondence analysis is a multivariate method to calculate the relationships between biological assemblages of species and their environment (Ter Braak and Verdonschot, 1995). CCA reveals association between aquatic insect species and environmental variables at different sites. Eigenvalues associated with each axis equal the correlation coefficient between species scores and site scores (Gauch, 1982). Thus an Eigen value close to 1 will represent a high degree of correspondence between species and sites, and an Eigen value close to zero will indicate very little correspondence (Palmer, 1993). In the present study total eigenvalue 0.205 in first year and 0.235 in second year indicated a medium to low degree of correspondences between species and stretches.

Environmental variables with long arrows are more strongly correlated with the ordination axes than those with short arrows (Ter Braak, 1987). In the first year the axis 1 was found to be strongly associated with $\mathrm{pH}$ and $\mathrm{F}-\mathrm{CO}_{2}$ but these two variables were found to be inversely associated with each other. In the second year axis 1 was strongly associated with phosphate and WT, again which were inversely associated with each other. In US in the first year, the three species Rheumatogonous sp., Aphelocheirus sp. and Ranatra varipes of order Hemiptera with their specialized air breathing organ (e.g., siphon in Ranatra, plastron in Aphelocheirus, Notonectidae, Mesoveliidae etc.) were found inversely correlated with all the measured variables.

Positive associations of Offadens sp. and Ovatametra sp. with phosphate and RF in midstream in the first year and positive correlation of Offadens sp. with nitrate in the second year in DS confirmed their capability to withstand high nutrient in water. The family Baetidae to which Offadens sp. belong is known for their occurrence in moderate polluted water (Alba-Tercedor et al., 1991). In the stream water phosphate concentration was found high ranging from 0.08 to $0.37 \mathrm{mg} \cdot \mathrm{L}^{-1}$. According to Sharon (1997) concentrations over $0.05 \mathrm{mg} \cdot \mathrm{L}^{-1}$ will likely have an impact while concentrations greater than $0.1 \mathrm{mg} \cdot \mathrm{L}^{-1}$ will certainly have impact on a river. In second year a group of species were found to be positively 
correlated with nitrate in DS. Concentration of nitrate also showed significant positive relationship with insect species richness in a lake, Phulbari anua of Cachar district, Assam (Gupta and Narzary, 2013). Ishaq and Khan (2013) also found positive correlation of concentration of nitrate and phosphate with density of Hemiptera which are mostly predators.

Although flow is a major determinant of physical habitat in streams and is a major determinant of biotic composition (Bunn and Arthington, 2002), in the present study association of insect species with flow rate was not recorded. In both the years DO was also not found to be associated with any species although DO content of the system was good. The three species (Ptilomera assamensis, Metrocoris sp., Rhagovelia sumatrensis) found in all the stretches were placed in centroid indicated their dependence more or less equal on all the environmental variables (Ter Braak, 1983). Metrocoris sp. showed strong positive relationship with $\mathrm{pH}$ and phosphate in the first and second year respectively while Ptilomera assamensis was strongly associated with $\mathrm{F}-\mathrm{CO}_{2}$ in first year, and with $\mathrm{RF}$ and $\mathrm{TA}$ in the second year.

FFGs of benthic macroinvertebrates is a potential effective tool for the assessment of the ecological integrity of streams and rivers (Lakly and McArthur, 2000). They provide a clear understanding of the influence of changing environmental conditions along vertical and latitudinal gradients (Pearson, 2001; Rosenberg, 2001). In the present study the correspondences between FFGs and stretches was also found low, i.e., eigenvalue $<1$. In the CCA ordination diagram predator group of both the years were found positively associated with $\mathrm{pH}$. Norazliza et al. (2014) also found significant positive correlation of species of Gerridae (mainly predatory in nature) with $\mathrm{pH}$ of water. A similar situation was also observed by Fox and Cham (1994) in their study of fast and slow flowing streams of the national botanical garden in Africa where species of Anisoptera, order Odonata had a significant positive correlation with $\mathrm{pH}$ of water. The collector in US, DS of first year and shredders in the MS of second year were positively correlated with phosphate. Their dominance in those stretches might be due to increased periphyton growth caused by nutrient availability and enhanced light (Gullan and Cranston, 2010) as the biofilm of periphyton is an important food source for shredders (Battin et al., 2003).

\section{CONCLUSIONS}

This study found that the aquatic insect community assemblage of the Bhalukjhora stream is governed by all the environmental variables and the major functional feeding group of the stream is predator across the stretches. The stream lacks sensitive species and there is preponderance of tolerant species who thrive well in moderately polluted water. Biomonitoring scores, like BMWP and SIGNAL also indicated moderate quality of water of the system although according to ASPT quality of water is good. Thus the present study reflects a moderate impact of the anthropogenic activity around the sanctuary in the stream water.

\section{ACKNOWLEDGEMENTS}

We thank the Head, Dept. of Ecology and Environmental Science for providing laboratory facilities. The first author thanks the University Grants Commission, New Delhi, India, for financial support. We thank the Principal Chief Conservator, Wild life, Assam for providing permission of collection of samples from the wildlife sanctuary and also thank all the members of the team involved in the field work for their help.

\section{REFERENCES}

Alba-Tercedor J., Zamora-Munoz C., Sanchez-Ortega A. and Guisasola I., 1991. Mayflies and stone flies from the RioMonachil (Sierra, Nevada Spain) (Ephemeroptera and Plecoptera). In: Alba-Tercedor J. and Sanchez Ortega A. (eds.), Overview and strategies of Ephemeroptera and Plecoptera. Sandhill crane press, Inc., Gainesville, pp. 529-538. 
Allan J.D. and Castillo M.M., 2007. Stream Ecology. Structure and Function of Running Waters, Springer, Dordrecht.

APHA (American Public Health Association), 2005. Standard Methods for the Examination of Water and Wastewater, 21st edition APHA, AWWA, WPCF Washington Dc, USA, 1368 p.

Armitage P.D., Moss D., Wright J.F. and Furse M.T., 1983. The performance of a new biological water quality score system based on macroinvertebrates over a wide range of unpolluted running-water sites. Water Res., 17, 333-347.

Baptista D.F., Buss D.F., Dias L.G., Nessimian J.L., Da-Silva E.R., De Moraes Neto A.H.A., De Carvalho S.N., De Oliveira M.A. and Rade L.R., 2006. Functional Feeding Groups Of Brazilian Ephemeroptera Nymphs: Ultrastructure Of Mouthparts. Ann. Limnol. - Int. J. Lim., 42, 87-96.

Battin T.J., Kaplan L.A., Newbold J.D. and Hansen C.M.E., 2003. Contributions of microbial biofilms to ecosystem processes in stream mesocosms. Nature, 426, 439-442.

Biodiversity Professional Version 2 for Windows, 1997. The Natural History Museum and Scottish Association for Marine Science.

BIS, 2004. Indian Standard Specification For Drinking Water IS 10500:2004, Bureau of Indian Standards.

Bouchard R.W., 2004. Guide to Aquatic Macroinvertebrates of the Upper Midwest, Water Resources Centre, University Of Minnesota, St. Paul, Mn., 208 p.

Bouchard R.W., 2009. Guide to Aquatic Invertebrate Families of Mongolia Identification, Manual for Students, Citizen Monitors, and Aquatic Resource Professionals, Chironomidae Research Group, University Of Minnesota, St. Paul, Mn 55108.

Boulton A.J., Boyero L., Covich A.P., Dobson M., Lake S. and Pearson R.G., 2008. Are Tropjcal Streams Ecologically Different from Temperate Streams? In: Dudgeon D. (ed.), Tropical Stream Ecology Academic Press, San Diego, pp. 257-284.

Braasch D., 2006. Compsoneuria (Siamoneuria) kovaci subg. N., Sp. N., A New Mayfly From Northern Thailand (Insecta, Ephemeroptera, Heptageniidae). Senck. Biol., 86, 47-53.

Brittain J.E., 1974. Studies on the Lentic Ephemeroptera and Plecoptera of Southern Norway. Norskent. Tidsskr, 21, 135-151.

Bunn S.E. and Arthington A.H., 2002. Basic principles and ecological consequences of altered flow regimes for aquatic biodiversity. Environ. Manage., 30, 492-507.

Chessman B., 1995. Rapid Assessment of Rivers Using Macroinvertebrates: A Procedure Based on Habitat-Specific Sampling, Family Level Identification, And A Biotic Index. Aust. J. Ecol., 20, 122129.

Chesters R.K., 1980. Biological Monitoring Working Party. The 1978 national testing exercise. Technical Memorandum 19.

Cummins K.W., 1973. Trophic Relations of Aquatic Insects. Ann. Rev. Entomol., 18, 183-206.

Cummins K.W., 1974. Structure and Function of Stream Ecosystems. Bioscience, 24, 631-641.

Cummins K.W. and Klug M,J., 1979. Feeding Ecology of Stream Invertebrates. Ann. Rev. Ecol. and Syst., $10,147-172$.

Cummins T. and Farrell E.P., 2003. Biogeochemical impacts of clearfelling and reforestation on blanket peatland streams I. Phosphorus. Forest Ecol. Manag. 180, 545-555.

Dudgeon D., 1999. Tropical Asian Streams: Zoobenthos, Ecology And Conservation, Hong Kong University Press, Hong Kong SAR, China.

Dudgeon D. and Wu K.K.Y., 1999. Leaf Litter in A Tropical Stream: Food Or Substrate For Macroinvertebrates? Arch. Hydrobiol., 146, 65-82.

Engelmann H.D., 1978. Zur Dominanzklassifikazierung von Bodenarthropoden. Pedobiologia, 18, 378-380.

Ensign H.S. and Mallin A.M., 2001. Stream water quality changes following timber harvest in a coastal plain swamp forest. Water Res. 35, 3381-3390.

EPA, 2010. Cooperation on emission inventories, trends, and mapping. U.S. Environmental Protection Agency, Washington, DC. Available at: www.epa.gov/airmarkets/progsregs/usca/coop.html.

Epler J.H., 2006. Identification Manual forthe Aquatic and Semi-Aquatic Heteropteraof Florida (Belostomatidae, Corixidae, Gelastocoridae, Gerridae, Hebridae, Hydrometridae, Mesoveliidae, Naucoridae, Nepidae, Notonectidae, Ochteridae, Pleidae, Saldidae, Veliidae), Florida Department of Environmental Protection, Tallahassee, FL, 186 p. 
Fox A.D. and Cham S.A., 1994. Status, Habitat Use and Conservation of the Scarce Blue-Tailed Damselfly Ischnura Pumilio(Charpentier) (Odonata: Coenagrionidae) in Britain and Ireland. J. Biol. Conserv., 68, 115-122.

Freitag H., 2004. Composition and Longitudinal Patterns of Aquatic Insect Emergence in Small Rivers of Palawan Island, The Philippines. Int. Rev. Hydrobiol., 89, 375-391.

Gauch H.G., 1982. Multivariate analysis and community structure. Cambridge University Press, Cambridge, England.

Gooderham J. and Tsyrlin E., 2002. The Waterbug Book: A Guide tothe Freshwater Macroinvertebrates of Temperate Australia. CSIRO Publishing, p. 240.

Gullan P.J. and Cranston P.J., 2010. The Insects an Outline of Entomology, 4th edition. John Wiley and Sons Ltd., 565 p.

Gupta S. and Narzary R., 2013. Aquatic insect community of lake, Phulbari anua in Cachar, Assam. J. Environ. Biol., 34, 591-597.

Gurung D.B., Dorji S., Tshering U. and Wangyal J.T., 2013. An annotated checklist of fishes from Bhutan. JOTT, 5, 4880-4886.

Hawkes H.A., 1998. Origin and Development of the Biological Monitoring Working Party Score System. Water Res., 32, 964-968.

Heino J., 2009. Biodiversity of aquatic insects: spatial gradients and environmental correlates of assemblage-level measures at large scales. Freshw. Rev., 2, 1-29.

Holmes K.L., Goebel P.C., Williams L.R. and Schecengost M., 2011. Environmental influences on macroinvertebrate assemblages in headwater streams of northeastern Ohio. J. Freshwater Ecol., 26, 409-422.

Irons J.G., Oswood M.W., Stout R.J. and Pringle C.M., 1994. Latitudinal Patterns In Leaf-Litter Breakdown - Is Temperature Really Important? Freshwater Biol., 32, 401-411.

Ishaq F. and Khan A., 2013. Seasonal limnological variation and macro benthic diversity of river Yamuna at Kalsi Dehradun of Uttarakhand. Asian J. Plant Sci. Res. , 3, 133-144.

Jessup B.K., Markowitz A., Stribling J.B., Friedman E., Labelle K.and Dziepak N., 2003. FamilyLevel Key tothe Stream Invertebrates of Maryland and Surrounding Areas, 3rd edition, Maryland Department of Natural Resources, Section 10, p. 98.

Lakly M.B. and McArthur J.V., 2000. Macroinvertebrate recovery of a post thermal stream: habitat structure and biotic function. Ecol. Eng. 15, S87-S100.

Lekprayoon C., Fuangarworn M. and Mongkolchaichana E., 2007. The Water Bugs (Hemiptera; Heteroptera) from the Western Thong Pha Phum Research Project Area, Kanchanaburi Province, Thailand, 38 BRT Research Reports.

Lenat D.R., Smock L.A. and Penrose D.L., 1980. Use of Benthic Macro Invertebrates as Indicators of Environmental Quality, pp. 97-114. In: Douglass L.W. (ed.), Biological Monitoring For Environmental Effects, Lexington Books, Toronto.

Maitland P.S., 1978. Biology of fresh waters, Ist edition, Blackie and Sons limited, Bishopbriggs Glasgow, G642 NZ.

Mandaville S.M., 2002. Benthic Macroinvertebrates in Freshwater - Taxa Tolerance Values, Metrics,and Protocols, Project H-1, Nova Scotia: Soil \& Water Conservation Society of Metro Halifax.

Manikannan R., Subramanian A. and Ali A., 2011. Seasonal variations of physicochemical properties of the Great Vedaranyam Swamp, Point Calimere Wildlife Sanctuary, South-east coast of India. African J. Environ. Sci. Technol., 5, 673-681.

Menke A.S., 1979. Family Belostomatidae, P. 76-86. In: A.S. Menke (ed.), The Semiaquatic And Aquatic Hemiptera Of California (Heteroptera: Hemiptera). Bull. Calif. Insect Surv., 21. University of California.

Merritt R.W. and Cummins K.W., 1996. An Introduction to the Aquatic Insects of North America, 3th editon, Hunt Publishing Company, Kendall, p. 862.

Merritt R.W., Cummins K.W. and Andrade P.C.N., 2005. The Use Of Invertebrate Functional Groups To Characterize Ecosystem Attributes In Selected Streams And Rivers In Southeast Brazil. Stud. Neotrop. Fauna E., 40, 71-90.

Miller K.B., 2005. Four New Species of Desmopachria Babington from Peru (Coleoptera: Dytiscidae). Zootaxa, 1059, 39-47. 
Nieser N., 2004. Guide to Aquatic Heteroptera of Singapore and Peninsular Malaysia III. Pleidae and Notonectidae. Raffles. B. Zool., 52, 79-96.

Nisbet T.R., 2001. The role of forest management in controlling diffuse pollution in UK forestry. Forest Ecol. Manage., 143, 215-226.

Norazliza R., Fauziah I., Mohd Rasdi Z., Fairuz K. and Ismail R., 2014. Comparison and relationship between water parameters and abundance of insects in field and irrigation system of paddy area of Sungai Burong, Tanjung Karang, Selangor, Malaysia. Agric. Forest. Fish., 3, 249-256.

Oliveira A.L.H. and Nessimian J.L., 2010. Spatial Distribution and Functional Feeding Groups of Aquatic Insect Communities in Serra Da Bocaina Streams, Southeastern Brazil. Acta. Limnol. Bras., 22, 424-441.

Palmer M.W., 1993. Putting Things in Even Better Order: The Advantages of Canonical Correspondence Analysis. Ecology, 74, 2215-2230.

Pearson T.H., 2001. Functional group ecology in the soft sediment marine benthos: the role of bioturbation. Oceanogr. Mar. Biol. Annu. Rev., 39, 233-267.

Polhemus J.T., 1984. Aquatic and Semiaquatic Hemiptera, In: Merritt R.W. and Cummins K.W. (eds.), An Introduction To The Aquatic Insects of North America, 2nd edition, Kendall/Hunt, pp. 231-260.

Popoola K.O.K. and Otalekor A., 2011. Analysis of Aquatic Insects' Communities of Awba Reservoir and its Physico-Chemical Properties. Res. J. Environ. Earth Sci., 3, 422-428.

Príncipe R., Gualdoni C., Oberto A., Raffaini G. and Corigliano M., 2010. Spatial-temporal patterns of functional feeding groups in mountain streams of Córdoba, Argentina. Ecología Austral, 20, 257-268.

Rieradevall M., Bonada N. and Prat N., 1999. Community Structure And Water Quality In The Mediterranean Streams Of A Natural Park (St. Llorená Del Munt, NE Spain). Limnetica, 17, 45-56

Rosenberg R., 2001. Marine benthic faunal successional stages and related sedimentary activity. Sci. Mar., 65, 107-119.

Runck C. andBlinn D.W., 1990. Population Dynamics and Secondary Production By Ranatra Montezuma (Heteroptera: Nepidae). J. N. Am. Benthol. Sot., 9, 262-270.

Sandin L. and Hering D., 2004. Comparing Macroinvertebrate Indices to Detect OrganicPollution Across Europe: A Contribution To The EC Water Framework Directivelntercalibration. Hydrobiologia, 516, $55-68$.

Sharon B., 1997. Definition of Water Quality Parameters. Source: Testing The Waters: Chemical And Physical Vital Signs Of A River By. Montpelier, VT: River Watch Network, ISBN-0-782-3492-3. Http://Fosc.Org/Wqdata/Wqparameters.Htm. Accessed on 20 June 2011.

Spence J.R. and Anderson N.M., 1994. Biology of water striders: interactions between systematics and ecology. Ann. Rev. Entomol., 39, 101-128.

Subramanian K.A. and Sivaramakrishnan K.G., 2005. Habitat and Microhabitat Distribution of Stream Insect Communities of the Western Ghats. Curr. Sci., 89, 25.

Subramanian K.A. and Sivaramakrishnan K.G., 2007. Aquatic Insects For Biomonitoring Freshwater Ecosystems-A Methodology Manual. (Asoka Trust For Research In Ecology And Environment (ATREE), Bangalore, India), p. 31.

Takhelmayum K., Gupta S. and Singh N.R., 2013. Diversity and Density of Aquatic Insects in the Lower Reach of River Moirang, Manipur, North East India. Proc. Natl. Acad. Sci., India, Sect. B Biol. Sci., 83, 575-584.

Ter Braak, C.J.F., 1983. Principal components biplots and alpha and beta diversity. Ecology, 64, 454462.

Ter Braak C.J.F., 1986. Canonical Correspondence Analysis: a new eigenvector technique for multivariate direct gradient analysis. Ecology, 67, 1167-1179.

Ter Braak, C.J.F., 1987. CANOCO-a FORTRAN program for canonical community ordination by (partial) (detrended) (canonical) correspondence analysis, principal components analysis and redundancy analysis (version 2.1), Agricultural Mathematics Group, Wageningen, $95 \mathrm{p}$.

Ter Braak C.J.F., 1988. CANOCO - An Extension of DECORANA to Analyze Species-Environment Relationships. Vegetation, 75, 159-160.

Ter Braak C.J.F. and Verdonschot P.F.M., 1995. Canonical Correspondence Analysis and related multivariate methods in aquatic ecology. Aquat. Sci., 57, 255-289. 
Thirumalai G., 1999. Aquatic and Semi-Aquatic Heteroptera of India, Indian Association of Aquatic Biologists, Hyderabad, 7, $74 \mathrm{p}$.

Thirumalai G., 2002. A Checklist of Gerromorpha (Hemiptera) From India. Rec. Zool. Soc. India: J. Indian Zool., 100, 55-97.

Trimmer W.L., 1994. Estimating Water Flow Rates. Oregon State University, The U.S. Department of Agriculture, US.

Vannote R.L., Minshall G.W., Cummins K.W., Sedell J.R. and Cushing C.E., 1980. The River Continuum Concept. Can. J. Fish. Aquat. Sci., 37, 130-137.

Wallace J.B. and Webster J.R., 1996. The Role of Macroinvertebratein Stream Ecosystem Function. Ann. Rev. Entomol., 41, 115-1139.

Waters T.F., 1977. Secondary Production In Inland Waters. Adv. Ecol. Res., 10, 91-164.

Webb J.M. and Suter P., 2001. Identification of Larvae of Australian Baetidae (Ephemeroptera). La Trobe University. Available at: Http://Wiki.Trin.Org.Au/Pub/Mayflies/Taxonomicworkshops. Accessed on 25 July 2011.

Webb J.M. and Suter P.J., 2011. Identification of Larvae of Australian Baetidae. Museum Victoria Science Reports 15: 1-24. Available at: Http://Www.Museum.Vic.Gov.Au/Sciencereports. Accessed on 13 July 2011.

WHO, 2011. Guidelines for Drinking Water Quality, Fourth Edition, World Health Organization, p. 564.

Wilhm J.L. and Dorris T.C., 1968. Biological Parameters for Water Quality Criteria. Bioscience, 18, $477-481$.

Cite this article as: B. Barman and S. Gupta, 2015. Spatial distribution and functional feeding groups of aquatic insects in a stream of Chakrashila Wildlife Sanctuary, Assam, India. Knowl. Manag. Aquat. Ecosyst., 416, 37. 